\title{
PROSES PENGAMBILAN KEPUTUSAN UNTUK BERHENTI MENGGUNAKAN NARKOBA PADA MANTAN PECANDU NARKOBA DI WILAYAH DENPASAR
}

\author{
Mery S. Afriani*, Komang Ayu Kartika Sari \\ Program Studi Kesehatan Masyarakat Fakultas Kedokteran Universitas Udayana \\ *Email: afriani_merry@yahoo.co.id
}

\begin{abstract}
ABSTRAK
Berhenti menggunakan narkoba merupakan kesulitan terberat bagi seorang pecandu karena sering sekali pecandu mengalami sugesti serta rasa sakit. Penelitian ini bertujuan untuk menggambarkan perilaku penggunaan, pemulihan kecanduan narkoba, dan proses pengambilan keputusan untuk berhenti. Metode kualitatif dengan rancangan studi kasus digunakan dalam penelitian ini, dimana lima orang informan dipilih dengan menggunakan metode purposive sampling. Pengumpulan data dilakukan dengan wawancara mendalam yang selanjutnya dianalisis dengan menggunakan thematic analysis. Teknik pengecekan keabsahan data dilakukan dengan cara peer debriefing dan studi literatur. Hasil penelitian menunjukkan bahwa hanya dua informan yang melewati semua tahapan proses berhenti yang dimulai dari tahapan menilai informasi baru, melihat alternatif-alternatif yang ada, mempertimbangkan alternatif, membuat komitmen, dan bertahan meskipun ada feedback negatif. Faktor terbesar yang dapat mempengaruhi keberhasilan untuk berhenti menggunakan narkoba adalah niat kuat dalam diri dan adanya dukungan keluarga yang positif. Penelitian ini menunjukkan bahwa keberhasilan berhenti menggunakan narkoba dipengaruhi oleh niat dan adanya dukungan positif dari keluarga.

Kata Kunci : Pengguna Narkoba, Proses Pengambilan Keputusan, Dukungan Keluarga
\end{abstract}

ABSTRACT

Quitting drugs is one of the most challenging goal for a drug addict because the addicts frequently face withdrawal and pain. This study aims to describe drugs use behavior, rehabilitation of drug addiction and decision-making process to quit drugs. Qualitative method with case study approach was applied on this study. Five informants were selected by purposive sampling. Data were collected by in-depth interviews which then analysed with thematic analysis. Data validity techniques applied for the study were peer debriefing and literature review. Study result revealed only two informants went through all stages of quitting process, starting from receiving new information, exploring available alternatives, making commitment and sustaining despite presence of negative feedbacks. The biggest factors that influence success of quitting drugs are strong internal motivation and positive family supports. This study showed that strong internal motivation and positive family supports are influential to the success of quitting drugs.

Keywords: Drug, Decide, Family support

\section{PENDAHULUAN}

Narkotika dapat bermanfaat untuk kepentingan manusia apabila dipakai sesuai dengan dosis. Pada bidang kedokteran, narkotika sering digunakan sebagai obat bius dan penenang, namun dalam kenyataannya zat-zat tersebut sering disalahgunakan hingga dapat menimbulkan kerusakan fisik, mental, dan emosi seseorang. Pengguna narkoba di Indonesia bertambah setiap tahunnya. Diperkirakan jumlah penyalahguna narkoba sebanyak 3,8 juta sampai 4,1 juta orang atau sekitar 2,10\% sampai 2,25\% dari total seluruh penduduk Indonesia yang berisiko terpapar narkoba pada tahun 2014 (BNN, 2014). Jumlah kasus narkoba di Bali pada tahun 2012 sudah mencapai 862 kasus dan menduduki peringkat 10 dari 33 propinsi yang ada. Sedangkan pada tahun 2014 kasus narkoba di Kota Denpasar berjumlah 191 pengguna 
narkoba yang telah di rehabilitasi oleh BNN Kota Denpasar (Carolina, 2015), dan telah terjadi penurunan jumlah pengguna narkoba di Kota Denpasar pada tahun 2015 yaitu sebanyak 119 pengguna.

Proses pemulihan pecandu narkoba bukanlah suatu proses yang singkat dan dapat dilakukan dengan mudah. Seorang pecandu narkoba dapat mengalami fase relapse atau menggunakan narkoba kembali, walaupun sudah lama berhenti menggunakan. Willy (2005) menyatakan bahwa niat merupakan penyebab utama untuk dapat berhenti dari menggunakan narkoba.

Proses pengambilan keputusan untuk berhenti menggunakan narkoba perlu dipahami agar dapat membantu para pecandu yang berkeinginan berhenti menggunakan narkoba. Maka dari itu, penelitian tentang proses pengambilan keputusan untuk berhenti menggunakan narkoba di wilayah Denpasar perlu untuk dilakukan untuk dapat memahami aspek yang mendukung keberhasilan dalam mengambil keputusan berhenti dan tantangan yang dihadapi oleh pengguna narkoba.

\section{METODE}

Penelitian ini menggunakan rancangan kualitatif dengan pendekatan studi kasus. Lokasi dari penelitian ini dilakukan di Kota Denpasar. Peneliti melakukan wawancara mendalam kepada mantan pecandu narkoba yang dijangkau oleh Yayasan Dua Hati Bali, sebuah yayasan rehabilitasi korban narkoba. Penelitian dimulai dari tahap persiapan sampai dengan tahap penyusunan hasil penelitian yang dilakukan pada bulan Januari sampai dengan Juni 2016.

Teknik sampling yang digunakan adalah purposive sampling. Strategi pengumpulan data dalam penelitian ini menggunakan metode wawancara mendalam. Teknik wawancara mendalam dilakukan untuk dapat menggali informasi dari informan yang sifatnya sensitif, sehingga informan dapat terbuka dengan peneliti, selain itu dapat memberikan kesempatan kepada informan untuk menjelaskan sepenuhnya pengalaman informan tentang topik yang diteliti.

Data dianalisis dengan metode thematic analysis yang disesuaikan dengan tujuan penelitian. Keabsahan data dilakukan oleh dengan peer debriefieng dan studi literatur.

\section{HASIL \& DISKUSI}

\section{Gambaran Perilaku Penggunaan Narkoba}

Hasil penelitian menunjukkan bahwa semua informan memulai menggunakan narkoba pada masa remaja. Berawal dari rasa ingin mencoba mengetahui rasa narkoba tersebut hingga ingin menjalani hidup santai dan tenang:

"Saya pake kan tahun 94. Begini nih gini, dulu itu kan saya masih remaja masih bujangan kan. Pengen santai, pengen happy, pengen tenang. Itu kan obat penenang, saya kan ngga dapet kerja, pingin tidur berhari-hari itu dah pake obatnya, pingin makan tidur aja itu dah pake obatnya"

Sebelum menjadi pecandu aktif, rata rata informan menyatakan kurang paham mengenai narkoba dan bagaimana dan efek 
dari narkoba tersebut, "Kalo dulu kita sama sekali blank sekali, saya kena tahun 93-an itu pertama kali saya kena. Itu kita ngga tau apa-apa itu, narkoba itu apa ngga tau" (ref). Setelah menjadi pecandu, informan baru memahami bahwa narkoba mempunyai dampak buruk dan membuat rasa ketergantungan. "Ya begitulah, menyesal, karena yang pertama dapat merusak pola pikir kita, pandangan kita ke keluarga, yang kedua materi kita sudah habishabisan"

Berdasarkan pemaparan diatas dapat dilihat adanya rasa ingin tahu yang tinggi mengenai narkoba menjadi salah satu penyebabnya. Hal ini sesuai dengan penelitian yang dilakukan Purwandari (2007), menyatakan usia pertama kali menggunakan narkoba menunjukkan bahwa usia remaja merupakan usia rawan dalam penyalahguna narkoba, dan alasan mereka menggunakan narkoba disebabkan rasa ingin tahu yang besar terhadap narkoba.

Informan pada penelitian ini mengakui mengkonsumsi lebih dari satu jenis narkoba yang diawali denga pil yang dikonsumsi secara oral seperti pil koplo dan sabu-sabu. Dua informan mengaku pernah mencoba semua jenis narkoba yang ada dan menggunakan jenis heroin, yang merupakan jenis narkoba yang dapat mengalami kesulitan untuk berhenti. Kemungkinan penggunaan jenis sabu-sabu dari seluruh partisipan karena peredaran sabu di Bali memiliki persentase $34 \%$ dibandingkan dengan jenis narkoba lainnya. Selain itu sabu-sabu juga merupakan tiga besar jenis narkoba yang beredar di masyarakat Bali (BNN, 2014).
Seorang pecandu narkoba yang telah mengalami ketagihan akan terus menerus menggunakan narkoba. Berdasarkan pengalaman pengguna narkoba mengenai frekuensi penggunaan, sebagian besar informan mengaku menggunakan narkoba hampir setiap hari, dimana dalam sehari minimal sekali menggunakan narkoba. Seperti pernyataan dari salah satu partisipan berikut:

"Setiap hari, harus setiap hari. Minimal setiap hari sekali, sudah ngga makan nasi itu. Kalo lagi banyak uangnya bisa sehari sampe tiga kali empat kali. Iya minimal sehari sekali dah"

Dilihat dari pernyataan diatas, penggunaan narkoba yang dapat menimbulkan ketergantungan membuat mereka mengkonsumsi narkoba dalam sehari rata-rata minimal sekali, dan terkadang dapat menggunakan lebih dari sekali dalam sehari. Frekuensi penggunaan narkoba ini sejalan dengan hasil penelitian dari Hanifa (2013), yang menyatakan sebanyak 41 responden $(97,6 \%)$ mengkonsumsi metamfetamin lebih dari dari satu kali dalam sehari.

Narkoba yang masuk ke dalam tubuh memiliki efek yang berbeda-beda. Perasaan yang dirasakan oleh sebagian partisipan dari faktor obat saat setelah menggunakan menimbulkan efek bermacam-macam seperti, tidak bisa tidur, nafsu makan berkurang, merasa lebih pede, enjoy, dan menjadi lebih aktif. Hal tersebut sesuai dengan hasil yang didapat dari penelitian Junaiedi (2012), tentang faktor obat atau zat yaitu pada kehidupan seseorang terdapat pengaruh faktor obat atau zat tersebut yang ketika mereka 
menggunakan narkoba merasa lebih percaya diri dan dapat menyatukan mereka dengan teman dan lingkungannya. Selain itu adanya efek dari narkoba tersebut yang membuat seseorang ketagihan.

\section{Pengalaman dalam Masa Pemulihan}

Masa pemulihan merupakan sebuah proses yang diawali dengan tumbuhnya kesadaran untuk berhenti lalu mencari pengobatan ke dokter dan memutuskan untuk mengikuti program rehabilitasi. Proses berhenti diperlukan dukungan keluarga dan orang terdekat:

"Berhenti itu dulu ke dokter. Pengobatan napza aja, tapi ngga sempet di rehab. Dulu belum ada metadon. Ke dokter cuma dikasih untuk menghilangkan rasa sakit, menghilangkan perasaan sedih, menghilangkan rasa bingung itu dikasih. Yang kedua mulai pake lagi saya, bilang sama orang tua kebetulan orang tua kan sudah tau, orang tua bilang "kamu mau berhenti lagi ini, kalo mau berhenti sini tak obatin". Berobat lagi kerumah sakit Sanglah itu, terakhir ini. Pokoknya saya mau berhenti saya harus berhenti, semua sudah habis barang-barang saya sudah habis, sampe celana saya jual dulu"

Kendala dalam mengikuti program rehabilitasi adalah pembiayaan, yang membutuhkan biaya yang tinggi sehingga hanya orang-orang dengan tingkat sosial ekonomi menengah keatas yang dapat melakukannya.

Penelitian ini menunjukkan bahwa mengikuti rehabilitasi tidak menjadi jaminan untuk sembuh, karena sering sekali pecandu yang telah selesai program rehabilitasi kembali relaps menggunakan narkoba kembali. Niat untuk berhenti menggunakan narkoba lebih penting dibandingkan dengan hanya sekedar mengikuti program rehap. Beberapa informan tidak mengikuti program rehabilitasi narkoba oleh karena keterbatasan biaya, sehingga dalam pemulihannya mereka berusaha mengobati sendiri dengan cara mereka sendiri. Hal tersebut tidak sejalan dengan hasil penelitian dari Henderson, et al (2003) yang melakukan penelitian di Baltimore bahwa pengguna narkoba suntik yang pernah mengikuti program terapi substitusi metadon memiliki peluang untuk berhenti lebih besar dibandingkan dengan mereka yang tidak pernah mengikuti program pengobatan kecanduan narkoba.

Hampir seluruh informan pernah mengalami relaps, yakni sebuah peristiwa yang sering dialami oleh pecandu. Seseorang yang telah berhasil berhenti atau beberapa lama tidak memakai narkoba kembali memakai dan terus mengkonsumsinya. Dari hasil penelitian terdapat beberapa partisipan yang pernah mengalami relaps lebih dari sekali dan mengakui bahwa lingkungan pergaulan mempengaruhi partisipan untuk menggunakan narkoba kembali, seperti penuturan partisipan berikut:

"Iya, tahun 2016 berhenti totalnya. Sebelumnya berhenti, lagi make lagi make. Iya kalo aku make kan kalo ada momen-momen tertentu, kalo dulu kan tiap ada acara kita nongkrong sama suami sama temen-temen harus make, kita harus beli harus beli gitu. Kalo sekarang ya diajaknya pas momen-momen tertentu aja"

Berdasarkan hasil penelitian dari Odgen (2000) dikutip dari Purwandari (2007) menjelaskan bahwa selain teman 
sebaya, faktor-faktor yang mempengaruhi terhadap kekambuhan pada pengguna narkoba adalah situasi emosi yang negatif dan konflik interpersonal, selain itu terdapat faktor pendorong lainnya dalam perilaku relapse yang dapat terjadi karena adanya sugesti yang kuat dalam diri partisipan untuk menggunakan narkoba. Seperti pernyataan dari salah seorang informan menjelaskan bahwa sugesti untuk relapse pada diri pecandu narkoba pasti ada, dan akan muncul selama seumur hidup, namun sekali muncul pada otak hanya 10 menit, berikut penuturan dari partisipan:

"Dasarnya pokoknya orang yang berhasil berhenti harus dari diri sendiri, kalo dipaksa ngga bakal bisa, kalo dipaksa akhirnya bakal pura-pura berhenti, pura-pura fine lah. Akhirnya capek bosen, ngerasa bersalah trus ngebohongin orang tua akhirnya udahlah cut sampe disini ajalah, ya sampe sekarang berhasil gitu loh, biarpun relapse berkali-kali itu wajar. Karna sugesti untuk relaps itu akan muncul selama seumur hidup, tapi munculnya Cuma 10 menit aja diotak abis itu hilang, tapi kadang saya arahkan ke kerja, ngobrol bareng temen, 10 menit udah lewat"

Sugesti merupakan ketergantungan mental dan sugesti tidak akan hilang serta tidak dapat disembuhkan walaupun tubuh seorang pecandu sudah kembali berfungsi normal. Bagi mantan pecandu, masa pemulihan dari narkoba tersebut akan berlangsung selamanya. Hal tersebut didukung dengan hasil penelitian Purba (2007) yang melakukan wawancara kepada mantan pecandu narkoba yang mengatakan keinginan untuk berhenti menggunakan narkoba pada setiap orang pasti ada namun jika bertemu dengan teman-teman sesama pemakai yang pada akhirnya muncul sugesti untuk menggunakan narkoba lagi.

\section{Proses Pengambilan Keputusan Berhenti Menggunakan Narkoba}

Mengambil keputusan merupakan sebuah tindakan. Dalam proses pengambilan keputusan sesuai teori Janis \& Mann (1987) yang terdiri dari lima tahap yaitu menilai informasi baru, melihat alternatif-alternatif yang ada, mempertimbangkan alternatif, membuat komitmen, dan bertahan meskipun ada feedback negative.

Tahap 1: Menilai informasi baru

Ketersediaan

informasi mempengaruhi suatu tindakan yang akan diambil oleh informan. Saat proses pengambilan keputusan untuk berhenti telah ada, informan mencari informasi tentang cara berhenti dan bagaimana untuk berhenti dari orang terdekat seperti suami yang telah berhasil berhenti serta teman, orang lain, dokter atau petugas lapangan saat ia ingin berhenti menggunakan narkoba, seperti pernyataan berikut :

"Iya, pas itu sih satu nyari informasi sama temen yang sudah berhenti duluan, yang kedua konseling sama dokter sama PL dari yayasan juga"

Hasil penelitian ini memperlihatkan bahwa modal terbesar dan pendorong utama pada seorang pengguna untuk berhenti menggunakan narkoba adalah tekad atau niat pada diri sendiri. Pecandu narkoba yang memiliki niat yang kuat untuk berhenti menggunakan narkoba secara total 
cenderung akan memunculkan perilaku tidak menggunakan atau menyentuh narkoba sama sekali baik di rehabilitasi maupun diluar rehabilitasi. Hal ini sesuai dengan pernyataan dari Willy (2005), yang menyatakan niat merupakan modal yang sangat luar biasa. Niat tersebut harus dijalankan bagaimanapun risikonya.

Tahapan yang dialami oleh pengguna narkoba yang akan berhenti meliputi menilai informasi tentang cara berhenti, mencari pegobatan, mempunyai pengalaman buruk akibat kecanduan narkoba seperti, kesulitan ekonomi, adanya rasa jenuh dengan narkoba.

Adapun faktor pendukung yang dianggap dan dirasakan oleh mantan pecandu narkoba yang dapat memotivasi mereka untuk lepas dari narkoba dan membantu dalam menghindari kecanduan kembali yaitu dukungan keluarga dan orang terdekat. Semua partisipan mengutarakan mendapatkan dukungan positif dari keluarga. Hasil penelitian Parker (2009), menunjukkan bahwa keterlibatan anggota keluarga secara penuh memiliki dampak yang positif dan menguntungkan bagi proses penyembuhan mantan pengguna narkoba.

Tahap 2: Melihat alternatif-alternatif yang ada

Pada tahap kedua yaitu seorang pecandu yang sudah mendapatkan informasi dan mengetahui resiko yang akan dialami jika tetap menggunakan narkoba. Partisipan akan mencari tahu kerugian dan keuntungan dari alternatif yang ada untuk berhenti menggunakan narkoba. Pada tahap kedua ini terdapat partisipan pertama, ketiga, dan keempat saja yang melewati tahap ini, dimana partisipan berfikir jika ia masih menggunakan narkoba akan menimbulkan lebih banyak lagi hutang dan barang dirumah habis serta tidak dianggap oleh keluarga, sedangkan jika ia berhenti menggunakan narkoba partisipan akan dijauhi oleh teman-teman pengguna narkoba lainnya, namun disamping itu partisipan bisa menggunakan uang untuk kebutuhan sehari-hari dan kebutuhan anak, dan tidak memiliki banyak hutang.

Tahap 3: Mempertimbangkan alternatif

Setelah menilai alternatif selanjutnya partisipan akan memasuki tahapan ketiga yaitu mempertimbangkan alternatifalternatif yang ada, dimana berhenti atau akan tetap menggunakan narkoba dengan segala risiko yang akan dihadapi. Dari melihat keuntungan dan kerugian alternatif pada tahap kedua, partisipan pertama, ketiga, dan keempat mempertimbangkan segala keuntungan dan kerugian yang akan muncul nantinya dengan baik-baik. Dimana partisipan mengungkapkan jika ia berhenti menggunakan narkoba tidak ada kerugian yang dialami, sebaliknya ia akan mendapatkan banyak keuntungannya. Berdasarkan penelitian yang diperoleh partisipan mengungkapkan banyaknya keuntungan yang dirasakan, seperti dapat menabung, menjalani hidup secara teratur dan merasakan badan menjadi lebih sehat dan dianggap oleh keluarga saat pulang. Seperti pernyataan berikut dari beberapa partisipan:

Tahap 4: Membuat komitmen

Setelah menimbang alternatif yang ada dan telah yakin dengan keputusannya, maka pecandu memasuki tahap keempat 
dan mengambil sebuah perencanaan tindakan tertentu untuk dilaksanakan dan memaksa pecandu untuk membuat komitmen pada diri sendiri untuk berubah dengan menghadapi segala risiko yang muncul. Setelah komitmen tersebut dibuat, maka pecandu harus menentukan waktu kapan akan melakukannya sampai berhasil dan memberikan hasil seperti yang diharapkan. Dari hasil penelitian ini memperlihatkan pada tahap keempat, pada proses pengambilan keputusan untuk berhenti menggunakan narkoba bahwa semua partisipan melewati tahap ini. Mereka membuat komitmen untuk berhenti menggunakan narkoba sampai ia benarbenar berhasil pulih. Adapun hal yang dilakukan dalam membuat komitmen, dimana partisipan memutuskan untuk mencari pelarian dari teman-teman yang masih menggunakan dan terdapat pula pada partisipan lainnya yang memutuskan untuk melakukan detoksifikasi. Pada penelitian Sawitri (2012), mendapatkan hasil bahwa pengguna narkoba suntik yang tidak mengikuti program detoksifikasi mempunyai peluang lebih cepat untuk berhenti menggunakan narkoba suntik.

Dalam tahap ini juga sangat dipengaruhi oleh adanya dukungan orangorang atau kelompok yang dianggap penting oleh pecandu narkoba. Berdasarkan keuntungan yang didapat serta adanya dukungan dari keluarga dan orang terdekat membuat partisipan dapat membuat komitmen untuk berhenti menggunakan narkoba. Semakin hari partisipan mendapatkan penguatan untuk meneruskan berhenti menggunakan narkoba ketika mereka merasakan banyak keuntungan yang dirasakan tanpa narkoba.

Tahap 5: Bertahan meskipun ada feedback negative

Tahapan terakhir yaitu dimana akan bertahan pada komitmen tersebut meskipun terdapat umpan balik yang akan dihadapinya. Walaupun terdapat dampak negatif yang muncul selama melakukan komitmen, maka pecandu akan terus berjuang dan menghadapinya dengan penuh keberanian. Hasil penelitian ini memperlihatkan pada tahap kelima semua partisipan melewati tahap terakhir ini. Adapun dampak negatif dari hasil pengambilan keputusan tersebut yang dialami pada partisipan seperti dicurigai oleh teman-teman yang masih menggunakan narkoba sehingga disangka partisipan menjadi mata-mata polisi, adanya godaan dari teman yang masih menggunakan, dan mengalami sakaw. Namun dari berbagai dampak negatif tersebut semua partisipan dapat mengatasinya dengan caranya sendiri, seperti saat mengalami sakaw partisipan pasang badan dengan berusaha menahannya, dan melakukan pengalihan dengan kegiatan-kegiatan atau bermain dengan anak. Sedangkan pada partisipan lainnya melakukan pengalihan dengan merokok dan pergi jalan-jalan bersama suami.

\section{SIMPULAN}

Simpulan yang dapat dibuat yaitu sebagian besar partisipan terjadi perubahan pandangan mengenai narkoba dari sebelum menggunakan narkoba dan setelah menggunakan narkoba, dimana pertama 
kali mengenal dan menggunakan narkoba saat usia remaja. Hal tersebut diakibatkan adanya rasa ingin tahu yang tinggi terhadap narkoba. Hampir seluruh partisipan pernah mencoba narkoba jenis pil koplo dan sabu, namun terdapat dua orang partisipan pernah mencoba semua jenis narkoba dan penggunaan narkoba terlama dengan narkoba suntik yaitu jenis heroin. Partisipan mengutarakan perasaan yang mereka rasakan saat menggunakan narkoba menimbulkan efek bermacam-macam seperti, tidak bisa tidur, nafsu makan berkurang, merasa lebih pede, enjoy, dan menjadi lebih aktif.

Dalam masa pemulihan, sebagian besar partisipan tidak mengikuti program rehabilitasi sehingga partisipan berusaha mengobati diri sendiri, namun dengan begitu membuat partisipan lebih cepat pulih dibandingkan dengan partisipan yang mengikuti program rehabilitasi. Karena pada partisipan yang mengikuti program rehabilitasi lebih sering mengalami relapse.

Pada tahapan proses pengambilan keputusan untuk berhenti menggunakan narkoba yang terdiri dari lima tahap yaitu beberapa partisipan tidak melewati semua tahapan yang ada, hanya terdapat dua partisipan yang melewati semua tahap. Namun kelima partisipan sama-sama mengambil keputusan akhir, yaitu berhenti menggunakan narkoba. Adapun faktorfaktor yang mendukung berhasilnya berhenti menggunakan narkoba yaitu sangat dipengaruhi oleh niat yang kuat dalam diri dan adanya dukungan keluarga yang positif.

\section{DAFTAR PUSTAKA}

Badan Narkotika Nasional. (2014). Laporan Survei Perkembangan Penyalahguna Narkoba di Indonesia Tahun Anggaran 2014. Jakarta.

Carolina, B. (2015). Evaluasi Paska Advokasi Implementasi Inpres No.12 Tahun 2011 Tentang Pelaksanaan Kebijakan Dan Strategi Nasional P4GN Pada Instansi Pemerintah Dan Swasta Di Kota Denpasar Tahun 2015. Skripsi. Program Studi Ilmu Kesehatan Masyarakat Universitas Udayana, Denpasar.

Hanifa, F.F. (2013). Gambaran Tingkat Kecemasan Pada Pasien Rawat Inap Pengguna Metamfetamin (Shabu) Di RSKO Jakarta Tahun 2013. Skripsi. Program Studi Pendidikan Dokter, Fakultas Kedokteran dan Ilmu Kesehatan UIN Syarif Hidayatullah Jakarta

Junaiedi, J. (2012). Makna Hidup pada Mantan Pengguna Napza. Skripsi. Jawa Barat: Universitas Guna Darma.

Parker, M. (2009). Identifying the Role of Families within Treatment. United Kingdom: Department of Health.

Purwandari, E. (2007). Orientasi Nilai-Nilai Hidup: Proses Pengambilan Keputusan Berhenti Mengkonsumsi Napza Life-Values Orientation: Decision-Making Processes. Jurnal Penelitian Humaniora, 8(2), 155-156.

Sawitri, H. (2012). Determinan Berhenti Pakai Narkoba Suntik (Studi Penyalahgunaan Narkoba di 17 Provinsi Tahun 2008). Thesis. Program Pascasarjana. Universitas Indonesia. Jakarta: Depok.

Utarini, A. (2007). Metode Penelitian Kualitatif di Bidang Kesehatan. Thesis. Program 
Arc. Com. Health • Desember 2017

ISSN: 2527-3620

studi Ilmu Kesehatan Masyarakat Willy, H. (2005). Berantas Narkoba Tak Program Pascasarjana Universitas Cukup Hanya Bicara: Tanya Jawab \& Gajah Mada, Yogyakarta Opini. Jakarta: UII Press. 